\title{
PORNOGRAPHy: HuMAN RIGHT OR HUMAN RIGHTS VIOLATION?
}

Author:

Elisabet le Roux ${ }^{1}$

\section{Affiliation:}

${ }^{1}$ Unit for Religion and

Development Research,

Department of Practical

Theology, Stellenbosch

University, South Africa

\section{Correspondence to:}

Lisa le Roux

email:

eleroux@sun.ac.za

\section{Postal address:}

Unit for Religion and

Development Research,

Faculty of Theology, 171

Dorp Street, Stellenbosch

7600, South Africa

\section{Keywords:}

Pornography; children; mass media; television; South African law; faith based organisations

\section{Dates:}

Received: 27 Oct. 2009

Accepted: 12 Apr. 2010

Published: 11 Oct. 2010

How to cite this article: Le Roux, E., 2010, 'Pornography: Human right or human rights violation?', HTS Teologiese Studies/Theological Studies 66(2), Art. \#847, 8 pages.

DOI: $10.4102 /$ hts.v66i2.847

This article is available at:

http://www.hts.org.za

(c) 2010. The Authors. Licensee: OpenJournals Publishing. This work is licensed under the Creative Commons Attribution License.

\section{ABSTRACT}

The article investigates the availability of pornographic media to under-aged users, specifically the already marginalised under-aged sector of the South African population. It argues that the availability of pornography is just another illustration of the systemic discrimination against this section of the population. Theoretical, non-experimental and clinical evidence illustrating the negative impact that the exposure to pornography has on children is presented against the background of the social reality of South Africa. The article finds that exposure to pornography leaves children even more vulnerable than they already are. The investigation of relevant legislation indicates that those who broadcast and/or sell pornography contravene South African law. The article concludes that the effects of pornography on children are far-reaching and potentially harmful. Children should be more effectively protected against exposure to pornography. Lastly, the role of faith-based organisations (FBOs) and the possibilities of their effective involvement, is explored.

\section{INTRODUCTION}

Section 16 of the Constitution of South Africa protects the individual's right to freedom of expression ${ }^{1}$. At the same time, Section 28 of the same Constitution states that the best interests of a child are of primary importance in every matter affecting the child ${ }^{2,3}$. Yet, within the context of pornography the social reality of South African society has created a situation in which, it will be argued, these two rights cannot mutually co-exist.

This article will look at how pornographic media is available to under-aged users, specifically the already marginalised under-aged sector of the South African population. It will argue that the availability of pornography is just one more way in which the systemic discrimination against this section of the population is taking place. This will be done by looking at theoretical, non-experimental and clinical evidence illustrating the negative impact that pornography exposure has on children and by exploring the social reality of South Africa in order to argue that it is a situation that leaves children even more vulnerable. The legislation relating to this debate will also be explored, in order to argue that those broadcasting and/or selling pornography are contravening some very fundamental South African laws. Lastly, the role of faith-based organisations ${ }^{4}$ (FBOs) in this issue will be discussed by looking at how FBOs can get involved effectively in addressing this important and worrying issue. ${ }^{5}$

A strong emphasis will be put on pornographic films and advertisements that are screened on free-to-air television ${ }^{6}$, as these are the pornographic sources that are most easily accessible and are completely free. Yet the article will also look at pornography available on the internet and via cellphone downloads ${ }^{7}$.

\section{Defining pornography}

Pornography is difficult to define (Malamuth et al. 2000:27-28; Fisher \& Barak 2001:313; Nelson 1982:172; Benedek \& Brown 1999:237). The reason for this difficulty is the moral and legal implications that stem from a definition. If certain material is labelled as pornographic due to a certain definition of pornography, the definition thus has moral and/or legal implications (Allen et al. 1995a:277).

The word itself comes from the Greek word pornographos which means 'the depiction of prostitutes, describing the life, manners, and customs of harlots and their patrons' (Nelson 1982:172). Within this

1.'(1) Everyone has the right to freedom of expression, which includes, (a) freedom of the press and other media, (b) freedom to receive and impart information or ideas, (c) freedom of artistic creativity and (d) academic freedom and freedom of scientific research' (South African Government 1996a).

2.'A child's best interests are of paramount importance in very matter concerning the child' (South African Government 1996a).

3.For the purposes of this article, a child means a person under the age of 18 years. This is the same as it is understood in Section 28 of the South African Constitution - a section that is dedicated to the rights of the child (South African Government 1996a).

4. As Unruh and Sider (2005) rightly claim, it is difficult to define exactly what a FBO is. But while Unruh and Sider continue by creating a typology of religious characteristics, by which you can differentiate between different kinds of FBOs, this article will give the term its broadest possible definition. Thus, in this article, the term is applicable to all organisations that are 'connected to a faith community and broadest possible definition. Thus, in this article, the term is applicable to all
is committed to some form of social involvement' (Unruh \& Sider 2005:104).

5.The Unit for Religion and Development Research (URDR) can be contracted by any party, private or public, to do research, consultation and/or training. This article is based on a research contract done in 2008 , on behalf of a client who wishes to remain anonymous. The client has considerable influence and was asked by community leaders of a very big informal settlement to address the issue of pornography on television and cellphones. As part of our client's process of addressing the situation, the URDR was contracted to do a desk-top study on the influence of pornography.

6.'(F)ree-to-air service means a service which is broadcast without encryption and capable of being received on universal receivers without payment by the end user to the broadcaster and without the use of receiving equipment...' (South African Government 1999).

7.The term 'cellphone downloads' refers to the service offered by companies which send subscribers pictures at a specified cost. The cellphone user must send a sms to a certain number and will then receive the picture. The cost is subtracted from the cellphone account. 
article, the definition of Allen et al. (1995a:259) will be used, who define pornography as 'media material used or intended to increase sexual arousal. Such material generally has verbal or visual images of exposed sexual organs and depictions of sexual behaviours.' This definition will be used as it is functional, receiver-orientated and meant for scientific research purposes (Allen et al. 1995a:259). Thus, though it is deficient for policy or judicial purposes, it is functional for research, as it gives a set of definitional limitations (Allen et al. 1995a:277).

\section{A confusing debate}

Much research has been done on the effects of pornography. Yet the results have been contradictory, debatable and confusing Scholars read the same evidence and interpret it in different and very often contradictory ways (Thompson et al. 1990:74). In the words of Allen et al. (1995b:5) '(the) controversy becomes more tangled and confusing despite the growing body of empirical efforts to establish what effects of exposure to pornography, if any, exist'. Thus within the scientific establishment there is no consensus about the effects of exposure to pornography (Allen et al. 1995a:259). This lack of consensus is not only present in research on the effects of pornography. Studies on the effects of media in general are delivering the same inconclusive, contradictory, contested results (Boyle 2000:187).

Yet this does not necessarily mean that media in general, and pornography specifically, has no effect. According to Boyle (2000) it rather means that research into the effects of media has consistently taken the wrong approach. In trying to provide scientific evidence that proves the negative effects of pornography, researchers have unwittingly provided more ammunition for arguing for the 'no-effect'. As each study provides evidence that can be criticised, the validity of the argument becomes weaker and weaker.

Because science has no way to answer the question, predictably the search for causation and the use of science leads most everyone to conclude that we just don't know enough to say for sure. But a shift in emphasis and method offers a way to state not The Truth (or conclude that we don't yet know The Truth), but a way to tell true stories and begin to make trustworthy moral and political decisions.

(Jensen in Boyle 2000:187-188)

Therefore, this article will attempt to avoid the traditional debate. It will not attempt to prove empirically that pornography leads to deviant sexual behaviour, nor will it try to prove the opposite. Rather, it will look at pornography specifically as it relates to the plight of children in a particular social and societal context. In the process, it will attempt to give an indication of what decisions will be trustworthy moral and political decisions.

\section{PORNOGRAPHY AND CHILDREN}

The fact that people perceive pornography as being harmful to children is revealed by the fact that most countries forbid the selling of pornography to children. This is also the case in South Africa ${ }^{8}$. A number of laws are in place to prevent children from being exposed to pornography'.

For obvious reasons, clinical studies on the effects of pornography on children cannot be extensive. Ethical considerations keep researchers from purposely exposing children to pornography in order to study its effects on them (Benedek \& Brown 1999:237). Furthermore, most parents would refuse to allow their children to participate in such a study and using children in a study without their parents' consent is unethical (Thornburgh \& Lin 2002:144).

8.For example, The Businesses Act, 71 of 1991, prohibits adult premises from even allowing those under 18 years of age onto their premises. The Act sets out what a business must do in order to prevent those younger than 18 years from seeing and or buying/accessing their wares (South African Government 1996b).

These laws will be discussed later in the article.
The South African government is making it clear that they believe that the exposure of children to pornography is a growing and very worrying issue. For example, the Film and Publication Board commissioned a survey on internet usage and the exposure of learners to pornography due to growing concerns about children's exposure to objectionable materials (Chetty \& Basson 2006:1). Also, the Deputy Minister of Home Affairs, Malusi Gigaba, had the following to say on this in the Budget Vote 4 speech on 10 June 2008:

There is growing demand to protect children from sexual exploitation as well as from exposure to illicit material ... It is important that we should try to accumulate as much information as possible about the crime of child pornography, the threat of technology to children as well as the exposure of pornography to children. We must not delude ourselves: staggering numbers of children in South Africa are at risk of or are being exposed to illicit material ...

(Gigaba 2008)

Yet even if one assumes that exposure to pornography is harmful to children - as most people do - if no clinical studies can be done, how does one know what these effects are? Certain theories explore and predict how pornography exposure can affect a child. Also, non-experimental studies and clinical observation also give us some clues about how pornography affects children.

\section{Child-development theory}

Theories on child-development show that all children (within a normal environment) go through predictable phases of sexual development ${ }^{10}$. Certain events and/or experiences such as viewing pornography - can disturb this process of sexual development. Viewing pornography can disturb - even accelerate - a child's appropriate, normal sexual development (Benedek \& Brown 1999:237-238).

Child-development theory also highlights the fact that the effects of exposure to any phenomenon are to a large extent influenced by the individual child's stage of development (Benedek \& Brown 1999:237). The individual's processing ability stands in direct relation to his or her age (Emmers-Sommer \& Allen 1999:490). The effects of exposure to pornography will thus be largely determined by the child's stage of development. ${ }^{11}$ Exposure to phenomena that are not age-appropriate can lead to, for example, sleep disturbance, nightmares [and] regressive behaviour, amongst other things (Benedek \& Brown 1999:237).

This links with what Kubey (1996) has to say on the role of first or early sexual gratifications in the development of sexual behavioural patterns. Early literature on sexual behaviour indicates a strong link between the specific and particular ways in which the individual's first or early sexual gratifications were obtained and the object or means of that gratification. What this means is that

[i]f one's primary means of sexual gratification at an early and impressionable age is via a particular technique or a particular object of desire, then there may be a kind of fixation on that technique and/or object.

(Kubey 1996:29)

A child's brain is programmed for sexual orientation during certain critical periods in childhood. Exposure to healthy sexuality and sexual norms can result in a healthy sexual

10.These phases are, (1) the pleasurable sensations from infant-mother contact, (2) differentiation between self and others and appreciation of own genitals, (3) incorporation of own sexual parts into a body concept, (4) limited exhibitionism, (5) expansion of erotic interests and (6) integration of genitals and genital function within self-concept (Benedek \& Brown 1999:237).

11.This finding is supported by a study done by Cantor et al (in Greenfield 2004). Ove 200 college students were asked to relate an instance where sexual media content had a strong effect on them. Almost 85 per cent reported that it was a movie that they were - according to the movie's rating - actually too young to see (Greenfield 2004:746). 
orientation, while exposure to pornography can lead to certain deviant behaviour becoming imprinted (Chetty \& Basson 2006:12) $)^{12}$.

Most sexual and pornography addictions are formed in middle childhood or early adolescence (Cline 2001:16). Thus, the viewing of pornography at too young an age can lead to the individual becoming fixated on either pornography as the means of sexual gratification, or on the specific type of sexual activity portrayed as the chosen means of sexual gratification.

\section{Modelling theory}

Modelling theory is based on the premise that observation creates acquisition. One need not necessarily directly and overtly perform a certain activity in order to learn it. 'As well as motor acts, the most diverse linguistic, conceptual and generalizable competencies can be developed or restored by vicarious means' (Rosenthal \& Bandura 1978:622). A model can be any stimulus array that is arranged in such a way that the observer can extract and act on the main information conveyed by surrounding occurrences, without needing to first actually carry it out (Rosenthal \& Bandura 1978:622)

Modelling has proven to be an important, powerful process through which children acquire complex processes (Birch 1980:490). Modelling theory also supports the idea that children may be harmed by viewing pornography, as sexuality shares with violence the propensity to elicit imitation (Benedek \& Brown 1999:238). The behaviour of children is influenced by what they are exposed to. This is especially true of television, as it is a medium with which many children spend a lot of time. Children as young as 14 months incorporate behaviours that they see on the television (Benedek \& Brown 1999:238).

Being exposed to pornography at too young an age thus may encourage premature sexual activity. As certain behaviours are seen on television, film, cellphone and/or internet and consequently legitimised, it is possible that children may start engaging in behaviour that is actually contradictory to familial and/or societal expectations (Benedek \& Brown 1999:238).

This is supported by Quayle and Taylor's (2002:332) discussion of the use of pornography in the 'seduction' of new victims when making child pornography. Paedophiles use pornography in order to 'soften' children. By showing them pornography they are socialised into seeing it as acceptable. It is used to 'break down the resistance and inhibitions of ... victims or targets of molestation ...' (Cline 2001:12) ${ }^{13}$ Material and behaviour that was originally seen as repulsive and immoral with time becomes acceptable and legitimised, as the child becomes desensitised. This idea that 'everybody does it' gives the child the permission to also do it (Cline 2001:4).

Thus, pornography has the ability to make children even more vulnerable. Chetty and Basson (2006:9) refer to a growing body of research evidence suggesting that for those under the age of 14 years, exposure to pornography is related to a greater involvement in deviant sexual practices (particularly rape). Exposure can lead to a child losing necessary inhibitions, inhibitions that would have prevented him or her from engaging in practices that are not age-appropriate and/or risky. It also puts the child more at risk for sexual abuse.

\section{Social learning theory}

Social learning theory states that 'both children and adults are often influenced by observing other humans, both by direct observations and via the media' (Malamuth \& Impett 2001:275). In as far as sexual behaviour and the media is concerned

12.Although Chetty \& Basson (2006) do not specify what 'healthy sexual norms' and 'deviant behaviour' are, the researcher recognises that such norms and deviance can to an extent be culture-specific.

13.See, for example, the study by Peters \& Navarro (in Cline 2001:12) or the study of Marshall (in Chetty \& Basson 2006:9) social learning theory suggests that both what is portrayed in the media and what may be left out ... may (a) affect interpretations, perceptions, attitudes, perceived norms, and other cognitive/ emotional processes; (b) teach novel modes of sexual behaviour; $(c)$ facilitate already learned behaviors perceived as socially acceptable; and/or (d) strengthen or weaken inhibitions concerning previously learned but socially discouraged forms of sexual behaviour.

(Malamuth \& Impett 2001:275)

Social learning theory thus argues that one of the ways through which people learn appropriate and inappropriate behaviour is through mass media, as mass media provides information regarding the rewards and punishments attached to these behaviours (Seto et al. 2001:39). The effectiveness of this type of learning depends on rewards and punishments that the viewers perceive and the viewers' evaluation about whether such rewards and punishments would also relate to them if they perform a similar action (Seto et al. 2001:39). ${ }^{14}$

Social learning theory proposes that people model the behaviour that they have seen and been exposed to (Mihalic \& Elliot 1997:21). Mass media is one of the role-players in an individual's learning process as it is a source of information and vehicle for learning of behaviour. Viewers base their decisions about behaviour on this information (Allen et al. 1995a:262). If pornography depicts certain kinds of adult sexual behaviour as positive and as eliciting positive consequences, it is possible that children viewing it may also see it as positive and as an acceptable act also for them, believing that they, too, can experience pleasure from doing it (Benedek \& Brown 1999:239) ${ }^{15,16}$

\section{Cultivation theory}

Another theory that offers an explanation for why media has such an effect on individuals looks at the idea of cultivation. This theory is based on the premise that mass media shapes an individual's perception of the social reality. Research has shown that people who watch a lot of television, for instance, have a perception of social reality that matches or is closely related to the social reality as it is portrayed by television (Donnerstein \& Smith 2001:299-300). Thus, if a child is exposed to an excessive amount of pornography, he or she may start seeing the world as a place where the sex and sexual situations portrayed in pornography is the norm. This can lead to a situation where the child starts to behave in a way that is in accordance with this perceived social reality.

This links with what Malamuth and Impett (2001) have to say on the process of decoupling fiction and reality. They theorise that humans do not have very highly attuned mechanisms

14.Social learning theory is sometimes accused of assuming that people are wax models that can be imprinted with any message by a role model (Bart \& Jozsa in Malamuth \& Impett 2001:275). This is not the case. Social learning is not simply copying what another is doing. It depends on the abstraction of rules regarding appropriate and inappropriate behaviour, and about the possible consequences of different courses of actions (Malamuth \& Impett 2001:275).

15.The reality of social learning in the lives of children is illustrated by the following two studies. Bryant (in Cline 2001:11) interviewed 600 teenagers about their involvement with pornography. Ninety-one per cent of the males and 82 per cent of the females had been exposed to hardcore pornography, and 66 per cent of the males and 40 per cent of the females stated that they wanted to actually try some of the sexual acts they had witnessed. Thirty-one per cent of the males and 18 per cent of the females admitted to actually doing some of these sexual acts within a few days of seeing the pornography. In the study by Bryant \& Rockwell, explored in Greenfield (2004:744), 13- and 14-year olds were exposed to video portrayals of in Greenfield (2004:74 ( regarding premarital and extramarital sex became more lenient after viewing these
videos. They were more accepting of such sexual relations between individuals videos. They were mo
(Greenfield 2004:744)

16.Berkowitz (in Donnerstein \& Smith 2001:299) is of the opinion that social learning theory does not fully explain why media has such a marked effect on people. Berkowitz believes that, when an individual sees an event via the media, ideas are activated that (for a short period of time) evoke or 'prime' other semantically related ideas and thoughts. After an idea has been activated it is more likely that it - and the associated ideas and thoughts - will come to mind again. And thus, it - and the associated ideas and thoughts - withe because the individuals now think of hings that they have viewed and are relating it to their own experiences, there is a greater likellhood of them acting in a way that is consistent with what was viewed. This process of thought activation is what
Berkowitz calls the 'priming effect' (Donnerstein \& Smith 2001:299). 
for distinguishing what is real from what is fictional, as our evolutionary environment did not pressurise us to develop such mechanisms. Storytellers told fictional tales, but it was easy to discriminate between story and reality. But now advanced, refined technology is telling the stories and it is not so easy anymore. That is why mass media has such a decided influence (Malamuth \& Impett 2001:274-275).

\section{SOCIAL RESPONSIBILITY}

Most people (and also the South African government) seem to agree that exposure to pornography has a negative influence on children, or at least that children should not be exposed to pornography.

Yet pornographic film is being shown on South African freeto-air television. ${ }^{17}$ According to the Code of the Broadcasting Complaints Commission of South Africa (BCCSA), these films must be broadcast within the watershed period ${ }^{18}$ - the period between 21:00 and 05:00 - and progressively more adult content is allowed with the advance of the watershed period (Broadcasting Complaints Commission of South Africa 2003) ${ }^{19}$ Broadcasters must assist the audience in choosing programmes by, for example, preceding it with guidelines as to appropriate age and content (Broadcasting Complaints Commission of South Africa 2003).

Yet placing an age restriction on a film when it is screened on television is not preventing South African children from viewing these films. ' $X X^{\prime}$ ' and ' $X 18^{\prime}$ ' films are according to South African law not allowed on television. But the broadcaster itself can determine what the rating and age restriction of a film is. While the Film and Publications Act instated a board that takes responsibility for rating films, broadcasters do not have to adhere to these regulations.

[A broadcaster] shall be exempt from the duty to apply for a classification of a film and...... shall in relation to the exhibition of a film not be subject to any classification made by the Board or any condition imposed in relation to the exhibition of the film by the Board.....

(South Africa 1996b)

Thus a broadcaster can decide on its own ratings.

South Africa has experienced a 91.3 per cent growth in internet users in the period between 2000 and 2008 (internetworldstats 2009). Currently, South Africa is fourth in the Africa Top 10 Internet Countries rating, with an estimated 4.6 million internet users (internetworldstats 2009). If one types in 'free porn' on Google, the most popular search engine in South Africa, one gets 53300000 hits..$^{20}$ Pornographic sites can be entered at the click of a button and pornography can be viewed at no cost. There is also no-one checking whether the person who is viewing the pornography is actually 18 years or older.

Companies advertise pornographic pictures, which are sent to an individual's phone for as low as R5. Anyone can sms these numbers. The companies advertise their wares on television, in newspapers and in magazines.

Thus, it is very easy for children in South Africa to access pornography. Literature shows that parental influence is the one

17.South Africa currently has four television stations that are available without a satellite dish or decoder. There are three state-owned South African Broadcasting Corporation (SABC) channels and a R225 p/a license fee is applicable to thes Corporito (SABC) che the pornographic film and advertisements.

18.Within the watershed period all programmes which contain scenes of violence sexually explicit conduct and/or offensive language which is meant for adult audiences must be broadcast. Such programming is not allowed outside of the watershed period (Broadcasting Complaints Commission of South Africa 2003).

19.For example, a certain film that may not be broadcast at 21:00 due to its content can be broadcast at 0:00

20.This was the number of hits on 16 July 2010 thing that can counter the negative influence of pornography on children (Greenfield 2004:746-748). But if parents are not in reasonable control of their households, their children, and their children's activities, then the socialisation process is (to say the least) undergoing some changes.

There are many households in South Africa where adequate parental guidance and influence are not present. Benedek and Brown (1999:239) highlight the disastrous consequences of this fact by stating that the children who are already most vulnerable within society - namely, children in single-parent homes, without parents, with mental and/or emotional problems, in dysfunctional families, and/or children who are mentally challenged or have been abused - are the children who are most at risk when it comes to pornography.

For broadcasters and companies to hold parents solely responsible for keeping children away from pornography is tantamount to ignoring the social reality of South Africa. South Africa is a country where 0.7 per cent (118 500 children) of all children under 17 years live in a child-headed household (Centre for Applied Legal Studies 2008). In South Africa, there are an estimated 2.5 million orphans (United Nations Children's Fund 2008). In 1998, 22 per cent of all South African households were single-parent households (Single Parent Centre 2008). This results in arguably millions of children who are not properly supervised.

Furthermore, in South African society there is resistance to talking about sex and sexual matters (Posel 2008:14). Even our laws recognise the dysfunctionality and problems present in our society. The new Sexual Offences Act of 2007, refers in its preamble, to the 'deep-seated, systemic dysfunctionality in our society', and it is one of the reasons for the existence of this new law (South African Government 2007, preamble).

Thus we have a society where there are millions of children who do not have parents or parental figures who can educate discipline and police their television, cell phone and internet habits. Furthermore we are a society afraid of, and hesitant to talk about, sex and sexual matters. If one is aware that in many homes, adequate parental control is not present and that pornography is easily accessed by children due to a broadcaster's or business's actions and if one is aware that pornography is harmful to children, one can argue that such a broadcaster or business is not honouring its duty to be socially responsible, as the broadcaster or business is wilfully creating a situation in which children are exposed to pornography.

\section{POLICY AND LEGISLATION}

It can be argued that broadcasters and companies broadcasting or selling pornography are not only being socially irresponsible, but that they are also contravening the law. A number of South African laws either refer to the exposure of children to pornography or are applicable to the situation. These will now be discussed.

\section{The Constitution of the Republic of South Africa, 1996}

The South African Bill of Rights includes a special section Section 28 - dedicated to the rights of the child. The Constitution recognises children as being among the most vulnerable members of society and thus in need of special protection.

Section 28 states that a 'child's best interests are of paramount importance in every matter concerning the child' (South Africa 1996a). Insofar as this clause is concerned, it can be argued that pornography on free-to-air television, advertised by companies selling it via cellphones, and available on the internet is violating the South African Constitution. 
Children are seeing the pornography on free-to-air television, on the internet and on cellphones. ${ }^{21}$ It can be due to inadequate parental supervision, absence of parents or guardians, by a deliberate violation of rules, or by accident.

Televised pornography and cellular pornography are meant for adult viewers. It can be argued that adults should not be prohibited from seeing such films or seeing the advertisements to buy it simply because children are then also exposed to it, because children are not supposed to watch it or buy it. But the Constitution demands that the 'child's best interest is of paramount importance in every matter concerning the child'. Pornography has negative effects on children. It is in their best interest that they are not exposed to pornography and that pornography be removed from television and advertisements. The child's right not to be exposed to pornography should be of more importance than the adult's right to pornography on freeto-air television stations and in advertisements. Adults can still access pornography in other ways, should they wish to. ${ }^{22}$

\section{THE CODE OF THE BROADCASTING COMPLAINTS COMMISSION}

It is argued by broadcasters that the pornographic films and advertisements televised at the moment in South Africa do not contravene the Code of the BCCSA. ${ }^{23}$ The Code has prescriptions regarding the screening time and content that is allowable. Yet the BCCSA's Code itself recognises that it will not provide regulations for best practices in every context. In Section 12, it is stated that

'The Code is therefore not a complete guide to good practice in every situation'. Nor is it necessarily the last word on the matters to which it refers. Views and attitudes change, and any prescriptions for what is required of those who make and provide programmes may be incomplete and may sooner or later become outdated. The Code is subject to interpretation in the light of changing circumstances, and in some matters it may be necessary, from time to time, to introduce fresh requirements.

(Broadcasting Complaints Commission of South Africa 2003, emphasis added)

Not violating the BCCSA's Code thus does not mean that a broadcaster is actually engaging in best practices. The Code itself realises and recognises this. Thus arguing that scheduled programming is in accordance with the prescriptions of the Code does not mean that one is engaging in socially responsible programming. Children are viewing the pornographic films and images due to the South African social reality and it can be argued that the 'changing circumstances' of which the Code speaks is now present and that 'fresh requirements' should be introduced.

21.A study targeting learners between the ages of 13 and 17 in schools in Cape Town, Johannesburg and Durban showed that $64 \%$ have seen pornographic images while on the internet and $70 \%$ have come across pornographic sites while on the internet. Also, $67 \%$ have seen one or more pornographic films, usually on DVD and $81 \%$ have seen pornographic images on a cellphone (Chetty \& Basson 2006:15-25).

22.The case of Dial-A-Porn in the United States of America is an example where the government chose the child's right not to be exposed to pornography over the right of the adult to pornography. Dial-A-Porn telephone numbers - which the ing of by children. Some or them act addicted to phoning Dial-A-Porn. Due to this, Congress passed legislation that prohibits obscene Dial-A-Porn messages and which restricts access to indecent messages (Cline 2001:10-11)

23.When protesters marched on the e.tv offices in 2007 and 2008, protesting against the pornographic films broadcasted by the station, e.tv's regulatory affairs executive officer, Olefile Bop Tshweu, had the following to say: 'We submit that in broadcasting that the time slot for these films is appropriate, the warnings are adequate, the content does not breach the code and there is no evidence that adequate, the content does not breach the code and there is no evidence that these films contribute to sexual crimes (emphasis added) (Citizen Reporter 2007). Head of publicity, Vasili Vass, stated that 'e.tv prescribes to the Broadcasting Complaints Commission of SA's code of conduct, which is sanctioned by Icasa, therefore whatever e.tv broadcasts must be lawful (Tissen 2008).

\section{Sexual offences Act (Act No. 32 of 2007: Criminal law [sexual offences and related matters] amendment Act, 2007)}

The Sexual Offences Act was passed in 2007. The Act was passed in order to have legislation in place that can address the sexual violence that is rife in South Africa. The Act has specific clauses which address the problem of children being exposed to pornography. Section 19 of this Act is particularly relevant in this regard and states that:

A person (' $A$ ') who unlawfully and intentionally exposes or displays or causes the exposure or display of -

(a) any image, publication, depiction, description or sequence of child pornography or pornography

(b) any image, publication, depiction, description or sequence containing a visual presentation, description or representation of a sexual nature of a child, which may be disturbing or harmful to, or age-inappropriate for children, as contemplated in the Films and Publications Act, 1996 (Act No. 65 of 1996), or in terms of any other legislation or

(c) any image, publication, depiction, description or sequence containing a visual presentation, description or representation of pornography or an act of an explicit sexual nature of a person 18 years or older, which may be disturbing or harmful to, or ageinappropriate, for children, as contemplated in the Films and Publications Act, 1996, or in terms of any other law,

to a child (' $B$ '), with or without the consent of $B$, is guilty of the offence of exposing or displaying or causing the exposure or display of child pornography or pornography to a child.

(South African Government 2007, s. 19)

Thus the law states that exposing a child to pornography is illegal, even if it is done with the consent of the child. Therefore, if a broadcaster screens pornographic films and/or images, or if a company is selling pornographic films and/or images, or a newspaper or magazine prints pornographic images, whilst knowing that children are seeing these films or images, due to whichever reason, it can be argued that such a broadcaster or company or publisher is contravening the law.

\section{FACING THE REALITY}

\section{The role of faith-based organisations}

What this article argues is that we are facing a stand-off in South Africa. On the one hand, the right to freedom of expression, as enshrined in the Constitution; on the other, one finds the Constitution stating that the child's best interests are always the most important issue.

The reality is that it is the already marginalised children who are most at risk when it comes to the issue of the wide availability of pornography. It is the children without parents, without proper supervision and guidance. They are the ones being exposed to pornography, for they have no-one who shields and protects them from it and thus they have a much greater chance of falling victim to all the negative effects of being exposed to pornography at too young an age. There is no-one who protect their rights, no-one with a big enough voice who will champion their cause.

Potentially there are four different ways in which FBOs can get involved in this issue. Firstly, they can take the legal avenue; secondly, they can take up the role of watch dog; thirdly, they can look at how they talk about sex and sexual matters and, fourthly, they can practically empower individuals and parents.

\section{Taking legal action}

Three laws were explored earlier on in this article and it was explained how broadcasters and businesses are infringing these 
laws. Thus there is room to take legal action in the issue of the broadcasting and advertising of pornography.

Some researchers argue that the attempt to police the spread of pornography is driven primarily by the need of certain groups to enforce their values onto others. They are of the opinion that morality policy theory explains this need of some to restrict access to pornography. Those opposing pornography really do so in order to force their values onto others (Smith 1999:23). If one looks at the way in which certain Christian groups are opposing pornography on free-to-air television, one can understand that many who see this believe that Christians do so in an attempt to enforce their value system onto others. This has lead to some quite negative critique against the Christian anti-pornography movement in South Africa.

Therefore, one should maybe find new ways of entering the debate, ways that are credible, ways that do not let one come across as a minority trying to enforce certain moral principles onto others. One option is to not attack the broadcasters and/ or companies directly, but to rather approach the issue through their governing bodies and/or the legislation that is applicable to their businesses. For example, by looking at children's rights and the South African social reality, it can be argued that broadcasters and businesses are infringing actual existing South African laws. One can also directly approach the BCCSA, arguing that the 'changing circumstances' to which their own code refers is now at hand and that 'new requirements' should be introduced into the Code. Approaching the issue in such a way will hopefully give the anti-pornography lobbyists a bit more weight and credibility. It will also - hopefully - lead to a more informed and aware public.

\section{A watch-dog}

It is important to be aware that our broadcasters, for example do not always obey the laws to which they are obligated to submit. Even though e.tv, for example, always defends their programming by stating that it is in accordance with the BCCSA's Code of Conduct (Tissen 2008), this is not always the case. e.tv has been guilty of changing the age restriction of a film without sufficient reason, of broadcasting a pornographic film of a nature and at a time that contravened the BCCSA, of giving inadequate classification regarding the content of films, of broadcasting promotional advertisements for adult films outside of the watershed period, etcetera (Broadcasting Complaints Commission of South Africa 2009).

It is important that the public complains when broadcasters, publishers and/or businesses violate laws and/or codes of conduct to which they have to adhere. If they are not brought to heel, they will do it again. The BCCSA takes such complaints quite seriously and broadcasters have been fined for their noncompliance. As governing bodies and codes of conduct in such matters are usually quite reliant on public opinion, it is important to give voice to complaints.

\section{Changing how faith-based organisations talk about sex}

DeLashmutt (2006:47) describes the type of sex that is promoted by pornographic sexuality as predominantly focusing on genital sexuality, with little time spent on developing romance, and/ or positioning sexuality within a relationship or community. But he - controversially - argues that the (Christian) church is guilty of the same focus and emphasis upon genital sexuality (DeLashmutt 2006:52).

The church strongly advocates sexual purity. Sexual acts must take place within a marriage. Furthermore, the Christian religion has a long tradition of condemning sexuality for its own sake. The purpose of sex is that of procreation (DeLashmutt 2006:52). While most churches are not that fundamentalist anymore, the focus on virginity that many espouse does also lead to an inordinate focus on genital sexuality. It does not matter what else the individual does, as long is the hymen stays in place. It does not matter what else goes on in a relationship, as long as they get married before they have sex. Such a focus on sexual purity also gives sex a genital focus. It is all about the deed and little time is spent on the context, relationship and community in which it occurs. To quote DeLashmutt (2006):

Prayers for restored virginity and Silver Ring Thing's fascination with teenage moral purity reflect a common tendency towards an overly genitally centred disembodied sexual ethic. Such a fascination removes the body from the sexual organs and contemplates a sexuality that is an isolated and commoditised experience. Sex in popular culture and in porn culture, in church and in the media, is all about a protected experience which exists outside of the realm of consequence.

(DeLashmutt 2006:55)

The church - and all FBOs - should thus start looking more holistically at the issue of sex. How they talk about sex and sexual matters must change, lest they stay guilty of contributing to disembodied sex, just like pornography.

\section{Practical ways of empowering individuals and parents}

There are certain things that the church can do to empower individuals and/or parents so that they and/or their children are not influenced by pornography exposure.

\section{Critical viewing}

Critical viewing is a skill that can be learnt by children, through which they are taught how to better interpret what they see in the media. Thus this is an important skill not only when it comes to pornography, but for media in general. If a child has these skills, he or she will be able to distinguish between real or unreal, factual or fictional, realistic or unrealistic. A child is also taught how to think about alternatives to the options given in the portrayed situation (Donnerstein \& Smith 2001:302).

If one takes into account the fact that many children do not have parents and /or parental role models, it could be very valuable if schools could teach children critical viewing skills.

\section{Parental guidance}

Studies on televised violence have shown the difference it makes if parents view programmes with their children and discuss the realities of violence with them. Such interaction can lessen the negative impact of the media (Donnerstein \& Smith 2001:302).

The researcher does not suggest that parents watch pornographic films with their children. But watching programmes with sexual content and afterwards discussing sex, the impact, alternatives, etcetera can lead to a child who is equipped to handle pornographic content, should he or she be exposed to it.

\section{Promote programs with positive sexual content}

The church can inform parents and people in general about programs and films with positive sexual content (Donnerstein \& Smith 2001:302). If what people are exposed to influence them, start exposing them to positive things!

\section{Address internet pornography}

The issue of internet pornography is difficult to address. While in South Africa it is illegal to host a pornographic site which has child pornography, other pornographic sites are allowed. South Africans also have access to sites from around the world. South Africa does not have jurisdiction over these sites.

Stack et al. (2004) did a study that suggests a way that the FBOs can help address this issue. They found that weak ties to religion and an unhappy marriage were strong predictors for the use of internet pornography. Thus, if an individual has strong ties to religion and a happy marriage, he or she is less likely to access internet pornography (Stack et al. 2004:86). 
These are areas in which FBOs can get involved. Faith-based organisations have the ability to help an individual develop stronger religious links and deeper faith. They also often have teaching, counselling and courses that can help an individual to develop a stronger marriage.

\section{Practical ideas}

Greenfield (2004:746-748) offers some practical ways for parents to counter the influence that pornography has on their children. These are:

- maintain an open family communication style

- be open to discussing sex with your children

- develop and maintain a warm and communicative parentchild relationship

- make sure your child gets sex education

- discuss media experiences with your child

- use the different forms of media with your child

- put the computer in a public place in your home

- restrict the use of Internet and other ways of accessing pornography.

\section{CONCLUSION}

It is not argued that all pornography should be banned. The effects of pornography on adults are the subject for another article. It is simply argued that the effects of pornography on children are so far-reaching and potentially negative that Section 16 of the Constitution should be more carefully applied. Honour Section 28 of the Constitution by removing pornographic content from free-to-air television stations and publications and by restricting the selling of pornography via cellphones. In doing so one can dramatically limit the ways that children are exposed to pornography. Adults can still access pornography in other ways.

The purpose of this article is to highlight the implications of the availability of pornography in South Africa and to hopefully thereby stimulate conversation about it. This is an issue in which FBOs have to become involved. It is no longer enough just to condemn the use of pornography. One has to become actively involved in protecting people from it. While the use of pornography will most probably always be a protected right under Section 16 of the South African Constitution, the ways in which children are being exposed to it can be addressed without violating Section 16.

At the moment, it is the marginalised children of our society who are most adversely affected by the current situation. They have no parents or parental figures that can protect, guide and discipline them. Faith-based organisations should step up in order to fill this role.

\section{REFERENCES}

Allen, M., D'Alessio, D. \& Brezgel, K., 1995a, 'A meta-analysis summarizing the effects of pornography II: Aggression after exposure', Human Communication Research 22(2), 258-283.

Allen, M., Emmers, T., Gebhardt, L. \& Giery, M.A., 1995b, 'Exposure to pornography and acceptance of rape myths', Journal of Communication 45(1), 5-26.

Benedek, E.P. \& Brown, C.F., 1999, 'No excuses: Televised pornography harms children', Harvard Review Psychiatry 7, 236-240.

Birch, L.L., 1980, 'Effects of peer models' food choices and eating behaviours on preschoolers' food preferences', Child Development 51, 489-496.

Boyle, K., 2000, 'The pornography debates: Beyond cause and effect', Women's Studies International Forum 23(2), 187-195.

Broadcasting Complaints Commission of South Africa, 2009, Judgments: E.tv, viewed 23 July 2009, from http://bccsanew. co.za/index.php?option=com_content\&task=category\&sect ionid $=1 \&$ id $=13 \&$ Itemid $=2$
Broadcasting Complaints Commission of South Africa, 2003, Code of the BCCSA, viewed 12 November 2008, from http:// www.bccsa.co.za/

Centre for Applied Legal Studies, 2008, Children's rights addressed by education facilities: Human rights organisation applauds KZN DOE decision to create boarding facilities at schools for orphans, viewed 07 November 2008, from http://web.wits.ac.za/NR/ rdonlyres/32C4015E-4D58-453C-91B8-34D01E405AA9/0/ KZNDOEBoardingschools.doc

Chetty, I. \& Basson, A., 2006, Report on internet usage and the exposure of pornography to learners in South African schools, viewed 14 November 2008, from http://www.info.gov.za/ view/DownloadFileAction?id $=81355$

Citizen Reporter, 2007, E.tv feels the heat over late night porn movies, viewed 26 May 2009, from http://www.citizen.co.za/index/ article.aspx?pDesc $=43347,1,22$

Cline, V.B.,2001, Pornography's effects on adults and children, viewed 07 November 2008, from http://www.moralityinmedia. org

DeLashmutt, M.W., 2006, 'The sexualisation of popular culture: Towards a Christian sexual aesthetic', Crucible $42-66$.

Donnerstein, E. \& Smith, S., 2001, 'Sex in the media: Theory, influences, and solutions', in D.G. Singer \& J.L. Singer (eds.), Handbook of children and the media, pp. 289-308, Sage Publications, Thousand Oaks, CA.

Gigaba, M., 2008, 'Speech delivered at the Budget Vote 4, National Assembly, Cape Town, June 10', viewed 14 November 2008, from http://www.info.gov.za/speeches/2008/08061111451002. htm

Emmers-Sommer, T.M. \& Allen, M., 1999, 'Surveying the effects of media effects: A meta-analytic summary of the media effects research', Human Communication Research 25(4), 478-497.

Fisher, W.A. \& Barak, A., 2001, 'Internet pornography: A social psychological perspective on internet sexuality', The Journal of Sex Research 38(4), 312-323.

Greenfield, P.M., 2004, 'Inadvertent exposure to pornography on the internet: Implications of peer-to-peer file-sharing networks for child development and families', Applied Developmental Psychology 25, 741-750.

Internetworldstats, 2009, Internet usage statistics for Africa, viewed 26 May 2009, from http://www.internetworldstats. com/stats1.htm

Kubey, R., 1996, 'Television dependence, diagnosis, and prevention: With commentary on videogames, pornography, and media education', in T.M. Williams (ed.), Tuning in to young viewers: Social science perspectives on television, pp. 1-46, viewed 31 October 2008, from http://www.mediastudies. rutgers.edu/depend.pdf

Malamuth, N.M. \& Impett, E.A., 2001, 'Research on sex in the media: What do we know about effects on children and adolescents?', in D.G. Singer \& J.L. Singer (eds.), Handbook of children and the media, pp. 269-287, Sage Publications, Thousand Oaks, CA.

Malamuth, N.M., Addison, T. \& Koss, M., 2000, 'Pornography and sexual aggression: Are there reliable effects and can we understand them?', Annual Review of Sex Research 11, 26-91.

Mihalic, S.W. \& Elliot, D., 1997, 'A social learning theory model of marital violence', Journal of Family Violence 12(1), 21-47.

Nelson, E.C., 1982, 'Pornography and sexual aggression', in M. Yaffé \& E.C. Nelson (eds.), The Influence of Pornography on Behaviour, pp. 171-248, Academic Press, London.

Posel, D., 2008, 'Getting the nation talking about sex: Reflections on the politics and "nation-building" in post-apartheid South Africa', viewed 19 November 2008, from http:// wiserweb.wits.ac.za/PDF\%20Files/sex\%20-\%20posel. PDF

Quayle, E. \& Taylor, M., 2002, 'Child pornography and the internet: Perpetuating a cycle of abuse', Deviant Behavior: $A n$ Interdisciplinary Journal 23, 331-361. 
Rosenthal, T.L. \& Bandura, A., 1978, 'Psychological modelling: Theory and practice', in S.L. Garfield \& A.E. Bergin (eds.), Handbook of psycho-therapy and behavior change: An empirical analysis, pp. 621-658, Wiley, New York.

Seto, M.C., Maric, A. \& Barbaree, H.E., 2001, 'The role of pornography in the etiology of sexual aggression', Aggression and Violent Behavior 6, 35-53.

Single Parent Centre, 2008, All about single parenting in South Africa, viewed 07 November 2008, from http://www. singleparentcenter.net/single-parenting/single-parentingin-south-africa.html

South African Government, 1996a, Constitution of the Republic of South Africa, no. 108, 1996, Government Printer, Pretoria.

South African Government, 1996b, Films and Publications Act, no. 65, 1996, Government Printer, Pretoria.

South African Government, 1999, Broadcasting Act, no. 4, 1999, Government Printer, Pretoria.

South African Government, 2007, Criminal Law (Sexual Offences and Related Matters) Amendment Act, no. 32, 2007, Government Printer, Pretoria.
Stack, S., Wasserman, I. \& Kern, R., 2004, 'Adult social bonds and use of internet pornography', Social Science Quarterly 85(1), 75-88.

Smith, K.B., 1999, 'Clean thoughts and dirty minds: The politics of porn', Policy Studies Journal 27(4), 723-734.

Thornburgh, D. \& Lin, H.S., 2002, Youth, pornography, and the internet, National Academy Press, Washington, DC.

Thompson, M.E., Chaffee, S.H. \& Oshagan, H.H., 1990, 'Regulating pornography: A public dilemma', Journal of Communication 40(3), 71-83.

Tissen, A., 2008, Groups protest against late night TV 'porn', viewed 26 May 2009, from http://www.citizen.co.za/index/article. aspx?pDesc $=56515,1,22$

Unruh, H.R. \& Sider, R.J., 2005, Saving souls, serving society: Understanding the faith factor in church-based social ministry, Oxford University Press, Oxford.

United Nations Children's Fund, 2008, Statistics: South Africa, viewed 23 July 2009, from http://www.unicef.org/ infobycountry/southafrica_statistics.html 